\title{
Peningkatkan Kompetensi Manajerial Pendidikan Kepala Madrasah Melalui Pembinaan Oleh Pengawas Madrasah
}

\author{
Musbahaeri \\ Kantor Kementerian Agama Kabupaten Wajo, Indonesia \\ e-mail: musbahaeri@gmail.com
}

\begin{abstract}
Abstrak
Madrasah supervisors who have the task of developing managerial education are expected to be able to play an active role in improving the managerial competence of the madrasa head. Madrasah supervisors are required to be active, creative, and innovative in applying and developing managerial supervision of education methods, namely monitoring and evaluation methods, reflection and Focus Group Discussion (FGD), Delphi, and workshops. Through this guidance, the headmaster will share, add insight, and consult with the madrasa supervisor so that in the end there will be an increase in managerial competence in education. The results of coaching by supervisors will be followed up by the madrasa head in managing the madrasa, and followed up by the madrasah supervisor in planning the next coaching, and followed up by the government in preparing the Shopping Professional Development program (PKB) for madrasah supervisors.

Keywords: Madrasah, Kepala Madrasah, Pengawas Madrasah, Kompetensi Manajerial Pendidikan.
\end{abstract}

\section{Pendahuluan}

Pengawas Madrasah, Kepala Madrasah dan guru merupakan tenaga pendidik dan kependidikan yang mutlak terstandarisasi kompetensinya secara nasional menurut PP No 19 tahun 2005. Karena pengawas, kepala madrasah dan guru adalah tiga unsur yang berperan aktif dalam madrasah. Guru sebagai pelaku pembelajaran yang secara langsung berhadapan dengan para siswa di ruang kelas, dan pengawas serta kepala madrasah adalah pelaku pendidikan di dalam pelaksanaan tugas Kepengawasan dan Manajerial pendidikan dalam satuan pendidikan yang meliputi tiga aspek yaitu supervisi, pengendalian dan inspeksi kependidikan.

Berdasarkan Peraturan Menteri Pendidikan Nasional (Permendiknas) Nomor 13 Tahun 2007 kepala madrasah dituntut untuk memiliki 5 kompetensi, yaitu: 1) kompetensi keperibadian; 2) kompetensi sosial; 3) kompetensi supervisi akademik; 4) kompetensi kewirausahaan; dan 5) kompetensi manajerial. Sementara pengawas sekolah/madrasah, berdasarkan pada Permendiknas No. 12 Tahun 2007, harus memiliki 6 kompetensi yaitu 1) Kompetensi kepribadian; 2) 
kompetensi supervisi manajerial; 3) kompetensi supervise akademik; 4) kompetensi evaluasi pendidikan; 5) kompetensi penelitian pengembangan: dan 6) kompetensi sosial.

Kemampuan yang harus dimiliki oleh kepala madrasah dalam kompetensi manajerial pendidikan adalah menerapkan prinsip-prinsip manajemen di madrasah mulai dari perencanaan, pelaksanaan, pemantauan, dan evaluasi untuk semua standar pendidikan yang ada. Sementara kemampuan yang harus dimiliki oleh pengawas dalam kompetensi manajerial pendidikan adalah membina kepala madrasah dalam pengelolaan dan administrasi satuan pendidikan berdasarkan manajemen peningkatan mutu pendidikan di madrasah. Jadi, kompetensi manajerial kepala madrasah dapat terus dikembangkan melalui pembinaan pengawas.

Dari pengalaman penulis di lapangan menunjukkan bahwa semua kepala madrasah binaan diangkat sebagai kepala madrasah tanpa dibekali melalui Pendidikan dan Pelatihan (Diklat) Calon Kepala Madrasah. Hal itu terjadi karena sebagian besar yayasan penyelenggara pendidikan juga tidak mensyaratkan kepala madrasah harus pernah mengikuti diklat calon kepala madrasah. Sehingga para kepala madrasah akan belajar secara otodidak tentang kompetensi yang harus dimilikinya sambil melaksanakan tugas. Hal ini tentu berdampak pada pengelolaan madrasah yang masih jauh dari standar yang ditetapkan oleh pemerintah. Masih untung kalau kepala madrasah yang diangkat mendapat panggilan Pendidikan dan Latihan (Diklat) yang berkaitan dengan tugasnya sebagai kepala madrasah. Tapi, itu pun sangat kurang. Tidak semua kepala madrasah, yang sudah "terlanjur" diangkat tanpa diklat, beruntung mendapatkan panggilan diklat.

Oleh karena itu, salah satu upaya yang bisa dilakukan adalah memberdayakan wadah KKM. KKM dapat memprogramkan kegiatan-kegiatan yang sifatnya pengembangan diri bagi kepala madrasah dalam mengelola madrasah. Salah satunya adalah kegiatan peningkatan kompetensi manajerial pendidikan yang menjadi salah satu kompetensi yang dituntut bagi kepala madrasah. Dalam hal ini tentunya dibutuhkan pula peran pengawas madrasah dalam mendampingi dan atau membina kepala madrasah dalam kegiatan tersebut.

Kegiatan kolektif seperti tersebut di atas dapat membantu para kepala madrasah dalam melaksanakan tugasnya. Mereka bisa saling berbagi antar sesama kepala madrasah, bisa pula bertanya dan berdisikusi dengan pengawas madrasah, dan bisa mengundang narasumber yang dianggap kompeten untuk membahas satu masalah, khususnya masalah kompetensi manajerial pendidikan kepala madrasah. 
Oleh karena itu pengawas harus terdepan dalam menggerakkan semua potensi madrasah, khususnya kepala madrasah dalam meningkatkan mutu pendidikan. Kehadiran pengawas harus senantiasa dinantikan oleh kepala madrasah, bukan malah dihindari atau malah "ditakuti". Diakui atau tidak, kualitas madrasah, baik dari segi akademik maupun manajerial, umumnya masih rendah. Dalam konteks ini peran pengawas madrasah sangat dibutuhkan sehingga para pengawas madrasah harus benar-benar memiliki dan bekerja sesuai dengan tuntutan profesionalismenya.

\section{Pembahasan}

Dalam Permendiknas No. 28 Tahun 2010 Bab I pasal 1 disebutkan bahwa Kepala Madrasah adalah guru yang diberi tugas tambahan untuk memimpin madrasah. Berdasarkan hal tersebut kepala madrasah memiliki fungsi ganda di madrasah yaitu sebagai guru dan kepala madrasah. Sehingga kepala madrasah harus memiliki dua jenis kompetensi sekaligus yaitu kompetensi guru dan kompetensi kepala madrasah.

Sebagai guru, kepala madrasah harus memeiliki 4 (empat) kompetensi yaitu kompetensi kepribadian, pedagogik, profesional, dan sosial. Sebagai kepala madrasah harus memiliki 5 (lima) kompetensi yaitu kompetensi kepribadian, manajerial, kewirausahaan, supervisi, dan sosial. Jadi, jika dipaduka maka kepala madrasah harus memiliki 7 (tujuh) kompetensi yaitu kompetensi kepribadian, pedagogik, profesional sebagai guru, manajerial, kewirausahaan, supervisi, dan sosial.

Salah satu di antara kompetensi kepala madrasah yang sangat penting dalam pengelolaan dan pengembangan madrasah adalah kompetensi manajerial pendidikan dalam mengelola suatu proses pendidikan sebagai top leader. Kompetensi manajerial pendidikan kepala madrasah adalah kemampuan kepala madrasah dalam merencanakan, melaksanakan, dan mengevaluasi kegiatan-kegiatan madrasah. Dalam pelaksanaannya mencakup pengembangan madrasah, pengelolaan segala sumber daya, pengelolaan ketatausahaan, pengelolaan sistem informasi, dan lain sebagainya. Dalam melasanakan perencanaan, pelaksanaan dan evaluasi dibutuhkan peran kepala madrasah sebagai pemimpin yang menjadi teladan, mengayomi, dan memberi motivasi.

Kompetensi manajerial pendidikan kepala madrasah dapat diuraikan satu persatu sebagai berikut:

1. Kepala Madrasah sebagai Perencana

Madrasah adalah sebuah system yang memiliki komponen inti yang terdiri dari input, process, dan output. Komponen-komponen tersebut harus berpadu satu 
sama lain karena merupakan satu kesatuan utuh yang saling terkait, terikat, mempengaruhi, membutuhkan, dan menentukan.

Selain kompenen inti dari sebuah sistem yang meliputi input, process, dan output, madrasah juga memliki akuntabilitas terhadap konteks pendidikan dan outcome. Konteks pendidikan berbeda dengan organisasi lain karena sifatnya yang intangible, pendidikan mengharapkan hasil/produk bukan semata-mata keluaran secara kuantitatif, tetapi outcome atau hasil yaitu lulusan yang bermanfaat pada masyarakat atau lingkungannya sesuai proses yang dilakukan.

Sebagai sebuah organisasi, yang di dalamnya memuat sebuah sistem, madrasah merupakan suatu sistem terbuka karena mempunyai relasi-relasi dengan lingkungan. Selain sebaga wahana pembelajaran, lingkungan juga merupakan tempat berasalnya masukan (input). Input madrasah dapat diidentifikasi mulai dari manusia, finansial, material/bahan-bahan, metode-metode, dan mesin-mesin. ${ }^{1}$

Untuk pengelolan semua input dibutuhkan perencanaan yang matang. Kepala madrasah harus menjadi perencana yang baik di madrasah. Perencanaan sebagai salah satu fungsi manajemen, adalah kegiatan yang sangat penting dalam suatu organisasi. Kesalahan dalam perencanaan maka hasilnya adalah kegagalan dalam output dan outcome.

Perencanaan adalah fungsi organik pertama dalam manajemen. Tanpa adanya perencanaan maka tidak ada dasar untuk melaksanakan kegiatan-kegiatan tertentu dalam rangka usaha mencapai tujuan. Perencanaan secara sederhana berarti keseluruhan proses pemikiran dan penentuan secara matang hal-hal yang akan dikerjakan di masa yang akan datang dalam rangka pencapaian tujuan yang telah ditentukan.

Berdasarkan hal tersebut, kebiajakan-kebijakan yang dirumuskan dalam suatu rencana mencakup struktur organisasi yang hendak disusun, rekrtumen serta pemberdayaan tenaga pendidik dan tenaga kependidikan, sistem dan prosedur yang hendak dipergunakan, serta ala-alat lainnya yang diperlukan untuk kelancaran kegiatan tersebut. ${ }^{2}$

${ }^{1}$ Aan Komariah dan Cepi Triatna, Visionary Leadership Menuju Sekolah Efektif, (Jakarta: Bumi Aksara, 2004), h. 1-3

${ }^{2}$ Sondang P. Siagian, Manajemen Sumber Daya Manusia, (Jakarta: Bumi Aksara, 2008), h.88 
Menurut H. Muhaimin dkk., perencanaan madrasah meliputi penentuan visi, misi, dan tujuan madrasah, rencana strategis pengembangan madrasah, rencana kerja tahunan madrasah, dan rencana biaya dan pendanaan. ${ }^{3}$

Jadi, peran kepala madrasah sebagai perencana adalah membentuk tim pengembang madrasah yang akan membantunya dalam perencanaan madrasah yang meliputi analisis kekuatan/kelemahan dan harapan/tantangan, perumusan rencana strategis pengembangan madrasah, penyusunan rencana jangka menengah, penyusunan rencana kerja tahunan, dan penyusunan rencana kegiatan dan anggaran madrasah.

\section{Kepala Madrasah sebagai Pengembang Organisasi Madrasah}

Keberhasilan madrasah adalah keberhasilan kepala madrasah. Untuk mencapai madrasah yang efektif, kepala madrasah harus menjadi pengembang yang baik. Madrasah efektif adalah suatu lembaga pendidikan Islam yang mempunyai kurikulum, strategi belajar mengajar yang efektif, dan ada interaksi dengan pihak yang berkepentingan (peserta didik, guru, orang tua, lingkungan dan pejabat yang terkait) dan menghasilkan keluaran yang dapat diandalkan. ${ }^{4}$

Salah satu konsep pengembangan madrasah adalah School Based Manajement (Manajemen Berbasis Sekolah). Manajemen Berbasis Sekolah (MBS) mulai muncul di Amerika Serikat ketika para orang tua dan masyarakat mempertanyakan relevansi pendidikan dengan tuntutan dan perkembangan masyarakat setempat. MBS memberikan otonomi yang luas pada madrasah dengan melibatkan masyarakat dalam kerangka kebijakan pendidikan nasional. Otonomi diberikan supaya madrasah lebih leluasa mengelola segala sumber daya dan sumber dana serta lebih tanggap terhadap kebutuhan masyarakat setempat. Di samping itu masyarakat akan ikut memahami, membantu, dan mengawasi pengelolaan pendidikan.

Dalam rangka melaksanakan MBS, kepala madrasah harus memiliki berbagai kemampuan di antaranya yang berkaitan dengan pembinaan disiplin guru dan pegawai serta pemberian motivasi dan penghargaan. Sehubungan dengah hal tersebut, kepala madrasah yang efektif dalam MBS dapat dilihat berdasarkan kriteria berikut:

a) mampu memberdayakan guru-guru untuk melaksanakan proses pembelajaran dengan baik, lancar, dan produktif;

b) dapat menyelesaikan tugas dan pekerjaan sesuai dengan waktu yang telah ditetapkan;

3 Muhaimin dkk., Manajemen Pendidikan: Aplikasinya dalam Penyusunan Rencana Pengembangan Sekolah/Madrasah, (Jakarta: Kencana Prenada Media Group, 2009), h.199-357

${ }^{4}$ Fatah Syukur, Manajemen Pendidikan Berbasis pada Madrasah, (Semarang: al-Qalam Press, 2006), h. 146 
c) mampu menjalin hubungan yang harmonis dengan masyarakat sehingga dapat melibatkan mereka secara aktif dalam rangka mewujudkan tujuan madrasah dan pendidikan;

d) berhasil menerapkan prinsip kepemimpinan yang sesuai dengan tingkat kedewasaan guru dan pegawai lain di madrasah;

e) bekerja dengan tim manajemen; dan

f) berhasil mewujudkan madrasah secara produktif sesuai dengan ketentuan yang telah ditetapkan. ${ }^{5}$

Berdasarkan hal tersebut, maka kepala madrasah harus punya kemampuan mengomunikasikan seluruh program madrasah kepada seluruh stakeholder agar perencanaan dapat terlaksana dengan baik. Begitu pula ketika kepala madrasah akan menetapkan suatu kebijakan, maka komunikasi kepada seluruh pemangku kepentingan harus diperbaiki agar kebijakan-kebijakannya dapat dipahami dan terlaksana dengan baik.

3. Kepala Madrasah sebagai Pemimpin Sumber Daya Madrasah (SDM)

Berbagai riset telah menemukan bahwa faktor pemimpin memegang peranan penting dalam pengembangan organisasi. Faktor yang paling dominan adalah karakter dari pemimpin tersebut sebagaimana telah dikemukakan oleh Covey (2005) bahwa 90 persen dari semua kegagalan kepemimpinan adalah kegagalan pada karakter. ${ }^{6}$

Kepemimpinan kepala madrasah terhadap SDM harus mengedepankan sifat kasih sayang dan mencintai. Kepala madarsah harus menyayangi dan mencintai orang-orang yang dipimpinnya. Nabi Muhammad SAW pernah mengatakan bahwa siapa saja yang tidak menyayangi maka tidak akan disayangi atau dengan kata lain siapa saja yang mau disayangi maka harus menyayangi. Dengan kemampuan menyayangi seorang kepala madrasah akan menjadikan SDM sebagai aset utama yang paling penting. Itulah sebabnya kemudian kepala madrasah dalam hubungannya dengan orang-orang dalam madrasah tidak lagi memosisikan diri sebagai atasanbawahan, tetapi akan memosisikan diri sebagai seorang pembimbing. Pembimbing

${ }^{5}$ E. Mulyasa, Manajemen Berbasis Sekolah: Konsep, Strategi, dan Implementasi, (Bandung: Remaja Rosdakarya, 2003), h. 118-126

6 Muhaimin dkk., Manajemen Pendidikan: Aplikasinya dalam Penyusunan Rencana Pengembangan Sekolah/Madrasah,h. 29 
tidak takut tersaingi dengan orang-orang yang dipimpinnya, justru dia akan mempersiapkan kadernya untuk menjadi pelanjut dalam kepemimpinan. ${ }^{7}$

Jadi, kepala madrasah selaku pemimpin SDM haruslah memimpin secara manusiawi dengan menjunjung tinggi hak-hak asasi orang-orang yang dipimpinnya agar tercipta budaya organisasi yang humanis dan mampu melahirkan calon-calon kepala madrasah melalui proses pembimbingan.

4. Kepala Madrasah sebagai Pemimpin Pembelajaran Madrasah yang Efektif

Madrasah sebagai organisasi pembelajar merupakan kumpulan dari individuindividu pembelajar yang ada di dalamnya. Ciri-ciri organisasi pembelajar adalah: (1) madrasah memberikan kesempatan dan mendorong setiap individu yang ada di dalamnya untuk terus belajar dan mengembangkan kapasitas dirinya, dan (2) madrasah tersebut merupakan organisasi yang siap menghadapi perubahan itu sendiri. $^{8}$

Jika semua personil madrasah selalu mengembangkan dirinya, maka secara otomatis kegiatan pembelajaran di madrasah akan berkualitas. Dan memang kegiatan pembelajaran di madrasah adalah kegiatan inti dari proses pendidikan yang harus terus ditingkatkan.

Di samping itu, kepala madrasah harus memastikan bahwa kurikulum yang dilaksanakan sesuai dengan visi misi madrasah. Pada setiap mata pelajaran ditekankan satu aspek yang mencerminkan visi misi madrasah. Misalnya, visi madrasah adalah mewujudkan peserta didik yang berwawasan sosial, maka pada setiap mata pelajaran disisipkan misi untuk mencapai visi tersebut. Contohnya, pada mata pelajaran Al-Quran Hadits diperkuat dengan ayat Al-quran dan Hadits yang menekankan perlunya hidup bermasyarakat, pada mata pelajaran Fiqih diperkuat hukum-hukum bermuamalat, pada mata pelajaran Aqidah Akhlak ditekankan keseimbangan antara hubungan kepada Allah dan hubungan kepada sesama manusia bahkan dengan alam.

Salah satu kompetensi kepala madrasah yang sangat terkait dengan perannya sebagai pemimpin pembelajaran adalah melaksanakan supervisi akademik. Tujuannya adalah untuk mengupayakan peningkatan kualitas proses pembelajaran sehingga menghasilkan output yang berkualitas pula. Teknik supervisi akademik

\footnotetext{
7 Muhaimin dkk., Manajemen Pendidikan: Aplikasinya dalam Penyusunan Rencana Pengembangan Sekolah/Madrasah,h. 33-36

8 Muhaimin dkk., Manajemen Pendidikan: Aplikasinya dalam Penyusunan Rencana Pengembangan Sekolah/Madrasah,h. 89
} 
yang bisa diterapkan adalah penilaian administrasi pembelajaran, observasi kegiatan pembelajaran, penilaian administrasi penilaian, dan supervisi klinis.

Hasil dari supervisi tersebut dievaluasi untuk mengetahui kelemahan dan kekuatan kegiatan pembelajaran untuk selanjutnya ditindaklanjuti dengan kegiatan penguatan atau pengembangan diri para guru yang masih memiliki kelemahankelemahan dan atau pemberian penghargaan bagi guru yang melaksanakan kegiatan pembelajaran yang berkualitas.

5. Sebagai Inovator Budaya dan Iklim Madrasah yang Kondusif

Sebagai sebuah organisasi, setiap madrasah memiliki budaya yang berbeda satu sama lainnya. Para ahli manajemen mengungkapkan bahwa budaya organisasi dapat mempengaruhi persepsi, pandangan, dan cara kerja orang yan gada di dalamnya. Apakah warga madrasah menunjukkan kegairahan, kedisiplinan, rasa suka atau moral-moral yang negatif seperti malas, kurang responsif, apatis, dan sebagainya. Dengan demikian, budaya organisasi merupakan suatu kekuatan yang tidak tampak tetapi dapat memengaruhi pikiran, perasaan, dan tindakan orang-orang yang bekerja dalam suatu organisasi. ${ }^{9}$

Defenisi budaya sekolah/madrasah, sebagaimana dirumuskan oleh Phillips, adalah "The believes, attitudes, and behaviors which characterize a school". Pada defenisi tersebut keyakinan, pendirian, sikap, dan perilaku menjadi inti dari karakter yang terbangun yang membentuk budaya madrasah. Sedangkan Deal dan Patterson mengartikannya sebagai "deep patterns of values, beliefs, and traditions that have formed over the course of the school's history". Dari defenisi tersebut dijelaskan bahwa budaya madrasah terbentuk melalui proses perjalanan sejarahnya melalui implementasi nilai-nilai, keyakinan, dan tradisi orang-orang di dalamnya. ${ }^{10}$

Oleh karena itu kepala madrasah harus menjadi inovator dalam membangun budaya dan iklim madrasah yang kondusif. Kepala madrasah bisa mengembangkan suatu tradisi baru yang baik yang belum pernah ada sebelumnya sebagai bentuk inovasi. Memang merubah tradisi di suatu madrasah tidaklah mudah karena biasanya orang-orang sudah merasa tenang dan nyaman dengan tradisi sebelumnya sehingga mereka akan cenderung menolak suatu tradisi baru karena khawatir tidak akan lebih baik dari sebelumnya. Berbagai tantangan pun dihadapi oleh kepala madrasah.

Misalnya, kepala madrasah ingin menerapkan budaya salaman dengan peserta didik pada pagi hari di pintu gerbang madrasah sebelum masuk kelas dan salaman

\footnotetext{
${ }^{9}$ Aan Komariah dan Cepi Triatna, Visionary Leadership Menuju Sekolah Efektif, (Jakarta: Bumi Aksara, 2004), h. 98

${ }^{10}$ Aan Komariah dan Cepi Triatna, Visionary Leadership Menuju Sekolah Efektif, (Jakarta: Bumi Aksara, 2004), h. 101
} 
ketika selesai kegiatan pembelajaran. Budaya ini bertujuan untuk membangun hubungan emosional antara guru dengan peserta didik dan juga untuk meningkatkan kedisiplinan guru dan peserta didik. Inovasi ini tentu akan mendapat banyak tantangan dari para guru yang tidak terbiasa datang pagi-pagi ke madrasah. Maka kepala madrasah harus menyampaikan idenya tersebut dengan bijak melalui forum rapat dan sosialisasi kepada peserta didik melalui rapat OSIS dan atau upacara.

6. Sebagai Pengelola Sarana dan Prasarana

Salah satu komponen penting dalam pengelolaan madrasah adalah sarana dan prasarana. Seringkali para orang tua dalam memilihkan madrasah bagi anak-anaknya memprioritaskan kondisi sarana dan prasarana madrasah. Menurut persepsi mereka bahwa penampilan fisik madrasah menjadi cerminan pengelolaan madrasah.

Memang disadari bahwa tanpa sarana dan prasarana pendidikan, proses pendidikan akan megalami kesulitan yang sangat serius, bahkan bisa menggagalkan pendidikan. Maka keberadaan sarana dan prasarana pendidikan mutlak dibutuhkan dalam proses pendidikan.

Sarana pendidikan adalah peralatan dan perlengkapan yang secara langsung dipergunakan dalam proses pembelajaran, seperti gedung, ruang kelas, meja, kursi, serta media pembelajaran. Sedangkan prasarana adalah fasilitas yang secara tidak langsung menunjang jalannya proses pembelajaran, seperti halaman, kebun, taman, dan jalan menuju madrasah. ${ }^{11}$

Kepala madrasah harus mampu mengatur serta menjaga sarana dan prasarana pendidikan agar dapat memberikan kontribusi pada proses pendidikan secara optimal. Kegiatan manajemen sarana dan prasarana meliputi kegiatan perencanaan, pengadaan, pengawasan, penyimpanan, inventarisasi, penghapusan, serta penataan atau perawatan. ${ }^{12}$

Dari beberapa kegiatan manajemen tersebut, yang paling sering kurang mendapat perhatian kepala madarsah adalah penataan atau perawatan. Kepala madrasah lebih fokus dan bersemangat untuk pengadaan dan lupa pada penataan dan perawatan. Hal ini membutuhkan perhatian untuk mentradisikan perawatan sarana dan prasarana di madrasah.

Program perawatan ini dapat dilaksanakan melalui langkah-langkah berikut ini:

a) Membentuk tim pelaksana perawatan preventif di madrasah.

b) Membuat daftar sarana dan prasarana.

\footnotetext{
${ }^{11}$ Mujamil Qomar, Manajemen Pendidikan Islam, (Jakarta: Penerbit Erlangga, 2010), h. 170

${ }^{12}$ E. Mulyasa, Manajemen Berbasis Sekolah: Konsep, Strategi, dan Implementasi, h. 49-50
} 
c) Menyiapkan jadwal tahunan kegiatan perawatan untuk setiap perawatan dan fasilitas madrasah.

d) Menyiapkan lembar evaluasi untuk menilai hasil kerja perawatan pada masing-masing bagian di madrasah.

e) Memberi penghargaan bagi mereka yang berhasil meningkatkan kinerja dalam rangka meningkatkan kesadaran dalam merawat sarana dan prasarana madrasah. ${ }^{13}$

\section{Sebagai Pengelola Humas}

Kepala madrasah perlu menagani masyarakat atau hubungan madrasah dengan masyarakat. Harus disadari bahwa masyarakat memiliki peranan yang sangat penting terhadap keberadan, kelangsungan, dan bahkan kemajuan madrasah. Setidaknya, salasatu parameter penentu keberhasilan madrasah adalah masyarakat. Bila ada madrasah yang maju, hampir bisa dipastikan bahwa salah satu faktor keberhasilannya adalah keterlibatan masyarakat yang maksimal. Sebaliknya, bila ada madrasah yang bernasib memprihatinkan, salah satu penyebabnya bisa jadi karena masyarakat enggan mendukung. ${ }^{14}$

Hubungan madrasah dengan masyarakat bertujuan antara lain untuk (1) memajukan kualitas pembelajaran dan pertumbuhan anak; (2) memperkokoh tujuan serta meningkatkan kualitas hidup dan penghidupan masyarakat; dan (3) menggairahkan masyarakat untuk menjalin hubungan dengan madrasah. Untuk merelisasikan tujuan tersebut banyak cara yang bisa dilakukan oleh madrasah. Antara lain dapat dilakukan dengan memberitahu masyarakat mengenai program-program madrasah, baik program yang telah dilaksanakan, yang sedang dilaksanakan, dan yang akan dilaksanakan sehingga masyarakat mendapat gambaran yang jelas madrasah yang bersangkutan. ${ }^{15}$

Di samping itu, ada lagi tujuan manajemen hubungan masyarakat yang esensial, yaitu sebagai berikut:

a) Untuk mendapatkan umpan balik dari masyarakat atas kebijakankebijakan yang ditempuh madrasah.

b) Untuk menunjukkan transparansi pengelolaan madrasah sehingga memiliki akuntabilitas publik yang tinggi.

13 Depdikbud, Panduan Manajemen Sekolah, TEP: Direktorat Pendidikan Menengah Depdikbud, 1998), h. 69

${ }^{14}$ Mujamil Qomar, Manajemen Pendidikan Islam,h. 183

${ }^{15}$ E. Mulyasa, Manajemen Berbasis Sekolah: Konsep, Strategi, dan Implementasi, h. 50-51 
c) Untuk mendapatkan dukungan riil dari masyarakat terhadap kelangsungan madrasah.

Untuk merealisasikan tujuan tersebut ada cara yang bisa dilakukan yaitu melakukan sosialisasi secara realistis argumentatif kepada masyarakat tentang program-program ideal yang telah dilaksanakan. Di samping itu madrasah harus bekerja sama dengan baik dengan masyarakat. Dalam kerja sama itu sebaiknya memenuhi syarat jujur, mulia, mencakup segala yang dibutuhkan, komprehensif, sensitif terhadap masyarakat, dan dapat dipahami oleh pihak yang lain. ${ }^{16}$ Oleh karena itu, madrasah dan masyarakat harus mempunyai hubungan yang harmonis. Madrasah menginformasikan program-program madrasah dan masyarakat meresponnya dengan memberi masukan-masukan atau bahkan memberikan bantuan berupa materil sebagai bentuk dukungannya terhadap madrasah. Harmonisasi antara madrasah dan masyarakat akan mewujudkan sinergitas yang baik dalam mencapai tujuan pendidikan nasional.

\section{b. Peran Pengawas dalam Meningkatkan Kompetensi Manajerial Pendidikan Kepala Madrasah}

Pengawas sebagai tenaga kependidikan memiliki peran membina kemampuan professional guru dan kepala madrasah dalam rangka meningkatkan kinerja madrasah. Peran pengawas madrasah sangat dibutuhkan dalam rangka peningkatan kualitas pendidikan madrasah, dan telah diperkuat kedudukannya melalui Peraturan Menteri Agama No. 2 tahun 2012 dan Peraturan Menteri Agama No. 31 tahun 2014.

Pengawas madrasah bertugas melakukan pengawasan terhadap dua hal yang sangat penting dalam pendidikan di madrasah, yaitu proses pendidikan (akademik) dan pengelolaan madrasah (manajerial). Proses pendidikan terkait dengan kegiatan pengembangan potensi pengetahuan, sikap, dan keterampilan peserta didik. Sementara pengelolaan madrasah berkaitan dengan pengaturan dalam memanfaatkan sumber daya sekolah secara efektif dan efisien. Dari sini tergambar bahwa pengawas madrasah memiliki peran yang strategis dalam proses dan hasil pendidikan yang bermutu. $^{17}$

Lebih lanjut dalam buku Panduan Kerja Pengawas Sekolah, disebutkan bahwa dalam pengawasan manajerial pengawas madrasah melakukan kegiatan pembinaan,

\footnotetext{
${ }^{16}$ Mujamil Qomar, Manajemen Pendidikan Islam,h. 185

${ }^{17}$ Barnawi dan Mohammad Arifin, Peningkatan Kinerja Pengawas Sekolah: Upaya Upgrade Kapasitas Kerja Pengawas Sekolah, (Yogyakarta: Ar-Ruz Media, 2014), h. 13
} 
pemantauan, penilaian, serta pembimbingan dan pelatihan profesional kepala sekolah dan tenaga kependidikan lain pada aspek pengelolaan dan administrasi sekolah yang terkait langsung dengan peningkatan efisiensi dan efektivitas sekolah dalam mendukung terlaksananya proses pembelajaran. ${ }^{18}$

Pembinaan pada pengawasan manajerial merupakan kegiatan pembimbingan yang dilakukan melalui bantuan profesional kepada kepala madrasah. Tujuannya adalah untuk meningkatkan kompetensi kepala madrasah dan tenaga kependidikan yang dibuktikan dengan meningkatnya kinerja. Pembinaan kepala madrasah meliputi materi sebagai berikut:

1. Kompetensi Kepribadian dan Sosial

2. Kepemimpinan Pembelajaran

3. Pengembangan Madrasah

a) Perencanaan Program (RKS/RKJM, RKT, dan RKAS)

b) Sistem Informasi Manajemen (SIM)

c) Evaluasi Diri Sekolah (EDS) dan Akreditasi lalu Merefleksikan HasilHasilnya dalam Upaya Penjaminan Mutu Pendidikan (pemenuhan $\mathrm{SNP}$;

d) Manajemen Sumber Daya

1) Pengelolaan Program Induksi Guru Pemula (PIGP)

2) Pengelolaan Penilaian Kinerja Guru (PKG) dan Tenaga Kependidikan

3) Pengelolaan Pengembangan Keprofesian Berkelanjutan (PKB)

4) Pengelolaan Kurikulum

e) Kewirausahaan; dan

f) Supervisi Pembelajaran. ${ }^{19}$

Menurut Subarna, sebagaimana dikutip oleh Barnawi, pembinaan mengandung pengertian memberikan pengarahan, memberikan bimbingan, memberikan contoh, dan memberikan saran dalam pelaksanaan pendidikan di madrasah. Memberikan pengarahan adalah upaya para pengawas agar yang diawasi dalam melaksanakan tugasnya lebih terarah mencapai tujuan yang telah ditetapkan. Memberikan bimbingan adalah upaya para pengawas agar yang diawasi mengetahui secara rinci kegiatan yang harus dilaksanakan dan cara melaksanakannya. Memberi contoh adalah upaya para pengawas agar suatu konsep yang dirumuskan dalam kurikulum atau pedoman lain yang sifatnya baru atau belum pernah dikenal oleh guru dapat dipahami oleh guru yang bersangkutan. Memberikan saran adalah upaya para pengawas agar sesuatu proses yang dilaksanakan di madrasah lebih baik daripada

\footnotetext{
${ }^{18}$ Depdikbud, Buku Panduan Kerja Pengawas Sekolah, (Jakarta: Depdikbud, 2017), h. 10

${ }^{19}$ Depdikbud, Buku Panduan Kerja Pengawas Sekolah, h.10
} 
hasil yang dicapai sebelumnya atau berupa saran kepada pimpinan untuk menindaklanjuti pembinaan yang tidak dilaksanakan sendiri. ${ }^{20}$

Menurut Jasmani Asf dan Syaiful Mustofa pengawas madrasah dalam melaksanakan program supervisi manajerial harus memberikan petunjuk perbaikan terhadap penyimpangan dalam pengelolaan madrasah yang meliputi beberapa hal sebagai berikut.

1. Kegiatan madrasah di bidang pengelolaan gedung dan bangunan, halaman, perabot, alat-alat kantor, dan saran pendidikan lainnya.

2. Pengembangan personel madrasah termasuk kepala madrasah, guru, tenaga tata usaha yang mencakup segi disiplin, sikap, dan tingkah laku, pembinaan karir, peningkatan pengetahuan dan keterampilan sesuai dengan tuntutan profesi masing-masing.

3. Tata usaha madrasah termasuk urusan keuangan, urusan sarana, dan urusan kepegawaian.

4. Hubungan madrasah dengan Komite Madrasah dan masyarakat. ${ }^{21}$

Lebih lanjut M. Tajuddin Nur sebagaimana dikutip oleh Barnawi mengatakan bahwa secara garis besar pola pembinaan pengawas madrasah adalah sebagai berikut:

1. identifikasi kebutuhan/profil madrasah, sebagai basis data/informasi untuk memetakan sasaran/ruang lingkup pembinaan;

2. menyusun program pembinaan;

3. melakukan supervisi, termasuk supervisi pembelajaran/klinis;

4. rapat-rapat, termasuk rapat koordinatif, direktif, dan konsultatif;

5. kunjungan rutin, baik dalam upaya pembinaan kelembagaan, ketenagaan, keuangan, dan lain-lain;

6. kunjungan khusus, seperti pemantauan penerimaan peserta didik baru, dan ujian-ujian;

7. pembinaan forum pendidik dan kepala madrasah, seperti KKG/MGMP dan KKKM;

8. studi dokumentasi. $^{22}$

\footnotetext{
${ }^{20}$ Barnawi dan Mohammad Arifin, Peningkatan Kinerja Pengawas Sekolah: Upaya Upgrade Kapasitas Kerja Pengawas Sekolah, h. 57

${ }^{21}$ Jasmani Asf dan Syaiful Mustofa, Supervisi Pendidikan: Terobosan Baru dalam Peningkatan Kinerja Pengawas Sekolah dan Guru, (Yogyakarta: Ar-Ruz Media, 2013), h. 107.

${ }^{22}$ Barnawi dan Mohammad Arifin, Peningkatan Kinerja Pengawas Sekolah: Upaya Upgrade Kapasitas Kerja Pengawas Sekolah, h. 58
} 
Dari beberapa argumen tersebut dapat dipahami bahwa tugas pengawas madrasah dalam membina kepala madrasah memang berat. Pengawas madrasah harus memiliki kompetensi yang lebih daripada kepala madrasah. Pengawas madrasah juga dituntut untuk kreatif dan inovatif dalam melaksanakan tugasnya. Kreativitas dan Inovasi harus terus dibangun oleh pengawas madrasah untuk mewujudkan kepala madrasah yang inovatif dan kreatif pula sehingga berdampak sampai kepada guru, peserta didik dan seluruh pemangku kepentingan madrasah. Olehnya itu, pengawas madrasah memang harus menguasai metode-metode pembinaan, baik dalam supervisi akademik maupun manajerial.

Ada beberapa metode yang bisa digunakan, khususnya dalam supervisi manajerial pendidikan untuk meningkatkan kompetensi manajerial pendidikan kepala madrasah, di antaranya sebagai berikut:

\section{Monitoring dan Evaluasi}

Monitoring adalah suatu kegiatan yang ditujukan untuk mengetahui perkembangan pelaksanaan penyelenggaraan kegiatan madrasah, apakah sudah sesuai dengan rencana, program, dan/atau standar yang telah ditetapkan, serta menemukan hambatan-hambatan yang harus diatasi dalam pelaksanaan program (Rochiat dalam Barnawi dan Mohammad Arifin, 2014; h. 45). Aspek-aspek yang dicermati dalam monitoring adalah pelaksanaan kegiatan sesuai program yang dikembangkan dan dijalankan oleh sekolah yang meliputi Rencana Pengembangan Madrasah, seperti Rencana Kerja Jangka Menengah (RKJM), Rencana Kegiatan dan Anggaran Madrasah (RKAM), Pemenuhan Standar Pelayanan Minimal (SPM) dan Standar Nasional Pendidikan (SNP). ${ }^{23}$ Jadi, monitoring atau pemantauan dalam kepengawasan dilaksanakan untuk memastikan terlaksana atau tidaknya suatu program madrasah dan/atau terpenuhi atau tidaknya Standar Pelayanan Minimal (SPM) untuk pendidikan dasar dan Standar Nasional Pendidikan (SNP) secara umum.

Kegiatan evaluasi ditujukan untuk mengetahui sejauhmana kesuksesan pelaksanaan penyelenggaraan program madrasah atau sejauhmana keberhasilan yang telah dicapai dalam kurun waktu tertentu. Tujuannya adalah untuk (1) mengetahui tingkat keterlaksanaan program; (2) mengetahui keberhasilan program; (3) mendapatkan bahan/masukan dalam perencanaan tahun berikutnya; (4) memberikan penilaian terhadap madrasah (Depdiknas dalam Barnawi dan Mohammad Arifin, 2014: h. 47). Hasil evaluasi dari pengawas madrasah akan menjadi bahan/dasar untuk

${ }^{23}$ Kementerian Pendidikan dan Kebudayaan: Direktorat Jenderal GTK, Konsep Supervisi Manajerial: Program Pengawas Sekolah Pembelajar Tahun 2016, (Jakarta: Kementerian Pendidikan dan Kebudayaan, 2016), h. 22 
perencanaan pembinaan berikutnya. Begitu pula bagi kepala madrasah, hasil evaluasi tersebut akan dijadikan sebagai bahan/dasar dalam perencanaan program madrasah berikutnya.

\section{Refleksi dan Focus Group Discussion}

Dalam paradigma baru, manajemen madrasah melibatkan seluruh pemangku kepentingan sehingga keberhasilan atau kegagalan suatu madrasah adalah keerhasilan atau kegagalan selurunya pula. Kepala madrasah, guru, pengawas madrasah, komite madrasah, staf tata usaha memiliki andil dalam menentukan keberhasilan madrasah. Dengan demikian metode refleksi dan focus group discussion menjadi salah satu metode yang bisa digunakan oleh pengawas madrasah.

Dalam metode ini, pengawas madrasah mempresentasikan hasil pemantauan dan penilaiannya secara terbuka di hadapan para pemangku kepentingan madrasah. Setelah itu mereka secara bersama-sama melakukan refleksi terhadap apa yang telah disampaikan oleh pengawas madrasah dan berusaha menemukan sendiri faktor-faktor penghambat serta pendukung yang selama ini terjadi dalam penyelenggaraan program madrasah. Kegiatan ini dilakukan dalam bentuk diskusi kelompok dan dapat dilakukan dalam beberapa putaran diskusi sesuai dengan kebutuhan. Tujuannya adalah untuk menyatukan persepsi stakeholder madrasah mengenai realitas kondisi madrasah dan menemukan langkah-langkah yang tepat untuk menanggapi realitas tersebut demi kemajuan madrasah. ${ }^{24}$

Langkah-langkah pelaksanaan FGD sebagai berikut:

a. Sebelum FGD dilaksanakan, semua peserta sudah mengetahui maksud diskusi serta permasalahan yang akan dibahas;

b. Peserta FGD hendaknya mewakili berbagai unsur sehingga diperoleh pandangan yang beragam dan komprehensif;

c. Pimpinan FGD hendaknya akomodatif dan berusaha menggali pikiran/ pandangan peserta dari sudut pandang masing-masing unsur;

d. Notulis hendaknya benar-benar teliti dalam mendokumentasikan usulan atau pandangan semua pihak;

e. Pimpinan FGD hendaknya mampu mengontrol waktu secara efektif, dan mengarahkan pembicaraan agar tetap fokus pada permasalahan;

${ }^{24}$ Barnawi dan Mohammad Arifin, Peningkatan Kinerja Pengawas Sekolah: Upaya Upgrade Kapasitas Kerja Pengawas Sekolah, h. 47-48 
f. Apabila dalam satu pertemuan belum diperoleh kesimpulan atau kesepakatan, maka dapat dilanjutkan pada putaran berikutnya. Untuk ini diperlukan catatan mengenai hal-hal yang telah dan belum disepakati. ${ }^{25}$

\section{Metode Delphi}

Metode Delphi dapat digunakan oleh pengawas dalam membantu pihak madrasah merumuskan visi, misi dan tujuan sekolah. Sesuai dengan konsep manajemen berbasis sekolah (MBS), dalam merumuskan Rencana Pengembangan Sekolah (RPS) harus dimulai dengan merumuskan visi, misi dan tujuan yang jelas dan realistis. Penyusunan visi, misi dan tujuan digali dari kondisi sekolah, peserta didik, potensi daerah, serta pandangan seluruh stakeholder. Metode Delphi dapat diterapkan oleh pengawas kepada kepala madrasah ketika hendak mengambil keputusan yang melibatkan banyak pihak.

Langkah-langkahnya menurut Gordon dalam Kemendikbud adalah sebagai berikut:

a. Mengidentifikasi individu atau pihak-pihak yang dianggap memahami persoalan dan hendak dimintai pendapatnya mengenai pengembangan madrasah. Masing-masing pihak diminta mengajukan pendapatnya secara tertulis tanpa disertai nama/identitas;

b. Mengumpulkan pendapat yang masuk, dan membuat daftar urutannya sesuai dengan jumlah orang yang berpendapat sama;

c. Menyampaikan kembali daftar rumusan pendapat dari berbagai pihak tersebut untuk diberikan urutan prioritasnya;

d. Mengumpulkan kembali urutan prioritas menurut peserta, dan menyampaikan hasil akhir prioritas keputusan dari seluruh peserta yang dimintai pendapatnya. ${ }^{26}$

4. Workshop Istilah lain dari workshop adalah lokakarya. Metode ini bersifat kelompok dan dapat melibatkan kepala madrasah, guru, dan staf madrasah serta komite madrasah. Selain itu, dapat pula melibatkan kelompok kerja kepala madrasah atau organisasi sejenis lainnya. ${ }^{27}$ Workshop dilaksanakan untuk mengatasi permasalahan manajerial pendidikan yang sama pada beberapa madrasah dalam satu wilayah binaan pengawas sekolah. Hasil

${ }^{25}$ Kementerian Pendidikan dan Kebudayaan: Direktorat Jenderal GTK, Konsep Supervisi Manajerial: Program Pengawas Sekolah Pembelajar Tahun 2016, h. 24

${ }^{26}$ Kementerian Pendidikan dan Kebudayaan: Direktorat Jenderal GTK, Konsep Supervisi Manajerial: Program Pengawas Sekolah Pembelajar Tahun 2016, h. 24

${ }^{27}$ Barnawi dan Mohammad Arifin, Peningkatan Kinerja Pengawas Sekolah: Upaya Upgrade Kapasitas Kerja Pengawas Sekolah, h. 49 
workshop diharapkan berupa produk yang dapat digunakan sekolah dalam meningkatkan mutu penyelenggaraan pendidikan di madrasah. ${ }^{28}$

Langkah-langkah pelaksanaan workshop sebagai berikut.

a. Menentukan materi atau substansi yang akan dibahas dalam workshop. Materi workshop terkait dengan masalah yang bersifat praktis, walaupun tidak terlepas dari kajian teori yang diperlukan sebagai acuan;

b. Menentukan peserta yaitu mereka yang terkait dengan materi yang dibahas.

c. Menentukan penyaji yang membawakan kertas kerja/materi;

d. Mengalokasikan waktu yang cukup;

e. Mempersiapkan sarana dan fasilitas yang memadai. ${ }^{29}$

Itulah empat metode yang disarankan kepada pengawas dalam membantu kepala madrasah mencapai visi, misi, dan tujuan madrasah dan tujuan pendidikan nasional. Pengawas madrasah bisa lebih kreatif dan inovatif lagi dalam melaksanakan pembinaan pada madrasah binaannya dengan mengembangkan metode-metode yang baru yang disesuaikan dengan kondisi dari madrasah binaan masing-masing.

Jadi, peran pengawas dalam peningkatan kompetensi manajerial pendidikan kepala madrasah akan sangat menentukan keberhasilan dan kemajuan madrasah. Sikap aktif pengawas madrasah dalam membina madrasah akan berdampak positif pada sikap kepala madrasah dalam mengelola madrasah. Sebaliknya sikap acuh pengawas dalam pembinaan madrasah akan melahirkan juga sikap acuh kepala madrasah dalam mengelola madrasah.

${ }^{28}$ Kementerian Pendidikan dan Kebudayaan: Direktorat Jenderal GTK, Konsep Supervisi Manajerial: Program Pengawas Sekolah Pembelajar Tahun 2016, h.25

${ }^{29}$ Kementerian Pendidikan dan Kebudayaan: Direktorat Jenderal GTK, Konsep Supervisi Manajerial: Program Pengawas Sekolah Pembelajar Tahun 2016, h.25 


\section{Simpulan}

Kompetensi manajerial pendidikan kepala madrasah meliputi tugas kepala madrasah sebagai perencana, pengembang madrasah, pemimpin SDM, pemimpin pembelajaran madrasah yang efektif, inovator budaya dan iklim madrasah, pengelola sarana dan prasarana, pengelola SDM, dan pengelola HUMAS. Peran pengawas madrasah dalam meningkatkan kompetensi manajerial pendidikan kepala madrasah adalah melakukan pembinaan dengan metode monitoring dan evaluasi, refleksi dan FGD, Delphi, dan workshop.

\section{Referensi}

Asf, Jasmani dan Syaiful Mustofa, Supervisi Pendidikan: Terobosan Baru dalam Peningkatan Kinerja Pengawas Sekolah dan Guru, Yogyakarta: Ar-Ruz Media, 2013.

A. Sahertian, Piet dan Ida Aleida Sahertian, Supervisi Pendidikan dalam Rangka Program Inservice Education, Jakarta: PT. Rineka Cipta, 1992.

Barnawi dan Mohammad Arifin, Peningkatan Kinerja Pengawas Sekolah: Upaya Upgrade Kapasitas Kerja Pengawas Sekolah, Yogyakarta: Ar-Ruz Media, 2014.

Direktorat Pendidikan Agama Islam, Dirjen Pendis, Kementerian Agama RI, Pedoman Pengawas Pendidikan Agama Islam, 2013.

http://awwals7.blogspot.co.id/2012/12/fungsi-peran-tugas-tanggungjawabkepala.html, diakses tanggal 30 Oktober 2017.

https://mmursyidpw.files.wordpress.com/2010/05/kompetensi-kepala-sekolah1.pdf, diakses tanggal 30 Oktober 2017.

Indrizal, Edi, Diskusi Kelompok Terarah Focus Group Discussion (FGD) (PrinsipPrinsip dan Langkah Pelaksanaan Lapangan), 2017.

Kementerian Pendidikan dan Kebudayaan: Direktorat Jenderal GTK, Buku Panduan Kerja Pengawas Sekolah Tingkat Dasar dan Menengah, 2017.

Kementerian Pendidikan dan Kebudayaan: Direktorat Jenderal GTK, Konsep Supervisi Manajerial: Program Pengawas Sekolah Pembelajar Tahun 2016, 2016.

Komariah, Aan dan Cepi Triatna, Visionary Leadership Menuju Sekolah Efektif, Jakarta: Bumi Aksara, 2004. 
Muhaimin, H. dkk., Manajemen Pendidikan: Aplikasinya dalam Penyusunan Rencana Pengembangan Sekolah/Madrasah, Jakarta: Kencana Prenada Media Group, 2009.

Mulyasa, E., Manajemen Berbasis Sekolah: Konsep, Strategi, dan Implementasi, Bandung: Remaja Rosdakarya, 2003.

Depdikbud, Panduan Manajemen Sekolah, TEP: Direktorat Pendidikan Menengah Depdikbud, 1998.

Paramita, Astridya dan Lusi Kristiana, TEKNIK FOCUS GROUP DISCUSSION DALAM PENELITIAN KUALITATIF (Focus Group Discussion Tehnique in Qualitative Research), Buletin Penelitian Sistem Kesehatan - Vol. 16 No. 2 April 2013: 117-127.

Peraturan Menteri Agama Nomor 2 Tahun 2012 tentang Pedoman Pengawas Pendidikan Agama Islam dan Perubahannya Nomor 31 Tahun 2013 tentang Pengawas Madrasah dan Pengawas Pendidikan Agama Islam pada Sekolah.

Peraturan Menteri Pendidikan Nasional (Permendiknas) Nomor 13 Tahun 2007 tentang Standar Kepala Sekolah/Madrasah

Peraturan Menteri Pendidikan Nasional (Permendiknas) No. 12 Tahun 2007 tentang Standar Pengawas Sekolah/Madrasah

Peraturan Pemerintah No 19 tahun 2005 dan Perubahannya No. 32 Tahun 2013 tentang Standar Nasional Pendidikan

Qomar, Mujamil, Manajemen Pendidikan Islam, Jakarta: Penerbit Erlangga, 2010.

Siagian, Sondang P., Manajemen Sumber Daya Manusia, Jakarta: Bumi Aksara, 2008.

Suhaimi, Uzair, FOCUS GROUP DISCUSSION: Panduan Bagi Peneliti Studi Kualitatif Studi Dampak Sosial Krisis Moneter Kerjasama BPS-ADB, 1999.

Sutaryadi, Administrasi Pendidikan, Surabaya: Usaha Nasional, 1990.

Sutaryadi, Administrasi Pendidikan, Surabaya: Usaha Nasional, 1990.

Syukur, Fatah., Manajemen Pendidikan Berbasis pada Madrasah, Semarang: alQalam Press, 2006. 